Salton, M. R. J., Honne, R. W. \& Cosslett, V. E. (1951). J. gen. Microbiol. 5, 405-407.

\title{
Electron Microscopy of Bacteria treated with Cetyltrimethylammonium Bromide
}

\author{
By M. R. J. SALTON, R. W. HORNE AND V. E. COSSLETT \\ Department of Colloid Science and the Cavendish Laboratory, University of Cambridge
}

SUMMARY: When viewed in the electron microscope, cells of Staphylococcus aureus, Streptococcus faecalis and Escherichia coli changed markedly when suspended in cetyltrimethylammonium bromide (CTAB) solutions instead of distilled water; the cytoplasm contracts away from the cell wall. The proportion of cells showing such contraction, in the case of Esch. coli, can be correlated with the proportion of cells killed by the treatment. High concentrations of CTAB appear to strip off the cell envelopes.

Direct evidence of cytolytic damage in detergent-treated bacteria was first provided by the electron micrographs of Mitchell \& Crowe (1947). They observed rupture of the cell wall concomitantly with the leakage of aminoacids from tyrocidin-treated Strep. faecalis. Dyar (1947) used cetylpyridinium chloride as a mordant, before staining bacteria and yeast with congo red and methylene blue. He noted that the cytoplasm of the cell appeared to have shrunk away from the cell wall. Meisel \& Umanskaya (1949) contributed further evidence of cytolytic damage resulting from treatment of a yeast with cetyl-zephirol; they observed contraction of the protoplast and its separation from the cell envelope.

The present paper presents evidence of cytological damage obtained by examination of CTAB-treated bacteria in the electron microscope. These observations have been made concomitantly with the studies of cell death, leakage of cell solutes and detergent adsorption reported by Salton (1951).

\section{METHODS}

The three organisms studied were Staph. aureus, Strep. faecalis ST (N.C.T.C. no. 6782) and Esch. coli H. Suspensions of the organisms, containing c. 1.5 mg. dry-weight cells $/ \mathrm{ml}$, were treated with concentrations of CTAB ranging from 45 to $900 \mu \mathrm{g} . / \mathrm{ml}$. The cells deposited on centrifuging samples of untreated and CTAB-treated bacteria were resuspended in distilled water, after the supernatants containing the released cell solutes had been decanted. Drops of dilute suspensions were placed on standard electron microscope specimen grids covered with nitrocellulose film. Mounted specimens were dried in a desiccator and shadowed with gold-palladium alloy $(60 \% / 40 \%)$ by shadowcasting technique (Wyckoff, 1949), at an angle of c. 45 degrees from the plane of the supporting film. A large number of untreated and treated bacteria were examined in the Siemens electron microscope. Most of the observations were made at direct magnifications of 8000-12000. The contrast between the outer cell wall and the supporting film 'background' was increased by using $20 \mu$. objective apertures. 


\section{RESULTS}

When suspensions of Staph. aureus cells in distilled water were held for periods of $30 \mathrm{~min}$. at $20^{\circ}$, no change in the appearance of the cells was observed; Pl. 1, fig. 1, shows the typical appearance of such cells. The cytoplasm in these cells is diffuse at its periphery near the cell wall. Exposure of Staph. aureus (c. $1.5 \mathrm{mg}$. dry wt. $/ \mathrm{ml}$.) to $90 \mu \mathrm{g}$. CTAB $/ \mathrm{ml}$. for $30 \mathrm{~min}$. at $20^{\circ}$ results in death of $99 \%$ of the cells and the release of an appreciable fraction of the cell solutes into the suspending fluid (Salton, 1951). Such cells showed a marked change in appearance, and shrinkage of the cytoplasm from the cell wall is clearly shown in Pl. 1, figs. 2, 3. Staph. aureus suspensions exposed to $90 \mu \mathrm{g}$. CTAB $/ \mathrm{ml}$. for $28 \mathrm{hr}$. at $30^{\circ}$ were Gram-negative and had decreased in dry weight by more than $30 \%$. Pl. 1, fig. 4, shows the partially digested appearance of such cells and the absence of cell walls. Treatment of Staph. aureus suspensions with $900 \mu \mathrm{g}$. CTAB $/ \mathrm{ml}$. for $30 \mathrm{~min}$. at $20^{\circ}$ stripped off the cell envelope, either partially as shown in Pl. 2, fig. 5, or completely as in Pl. 2, fig. 6.

In the case of Strep. faecalis, untreated cells (Pl. 2, fig. 7) cast little shadow, and therefore seem to lie flatly on the supporting film. As with Staph. aureus the cytoplasm is diffuse near the cell wall. When Strep. faecalis is treated with $90 \mu \mathrm{g}$. CTAB $/ \mathrm{ml}$. for $30 \mathrm{~min}$. at $20^{\circ}, 99 \%$ of the cells are killed and the release of cell solutes into the suspending fluid is complete. The contraction of the cytoplasm revealing the thin outer cell wall is shown in Pl. 2, fig. 8 .

Esch. coli cells from distilled-water suspensions are shown in $\mathrm{Pl}$. 3, fig. 9 Treatment of $c .1 .5 \mathrm{mg}$. dry weight of this organism with $45 \mu \mathrm{g}$. CTAB $/ \mathrm{ml}$. for 5 min. at $20^{\circ}$ result in the death of $c .30 \%$ of the cells and initiates the leakage of cellular constituents. Examination of cell suspensions treated under these conditions showed that in $\mathbf{3 0 - 4 0} \%$ of the cells the cytoplasm had contracted from the cell wall, the remaining 60-70 \% of the cells appearing more like the untreated cells; Pl. 3, fig. 10, shows a typical field. Pl. 3, fig. 11, shows that contraction of the cytoplasm had occurred in all cells when Esch. coli was exposed to sufficient CTAB (c. $90 \mu \mathrm{g} . / 1.5 \mathrm{mg}$. dry-weight bacteria) to kill virtually all the cells in $30 \mathrm{~min}$. When treated with $900 \mu \mathrm{g}$. CTAB $/ \mathrm{ml}$. for $30 \mathrm{~min}$. at $20^{\circ}$, the cell wall of Esch. coli appeared to be stripped off (Pl. 3, fig. 12).

\section{DISCUSSION}

Our observations are in agreement with earlier reports of cytological damage resulting from detergent treatment of micro-organisms (Mitchell \& Crowe, 1947; Dyar, 1947; Meisel \& Umanskaya, 1949). From the work of Salton (1951) and our observations it is evident that the damage caused by CTAB to the permeability barrier, resulting in the leakage of cell solutes, is accompanied by a marked contraction of the cytoplasm, which becomes detatched from the cell wall. For Esch. coli there is a correlation between the number of cells killed and the proportion of cells in which the cytoplasm has contracted from the cell wall.

On treating bacteria with sufficient CTAB to kill the cells and release cell solutes, cellular disorganization is manifest in the contraction of the cytoplasm 
Journal of General Microbiology, Vol. 5, No. 2

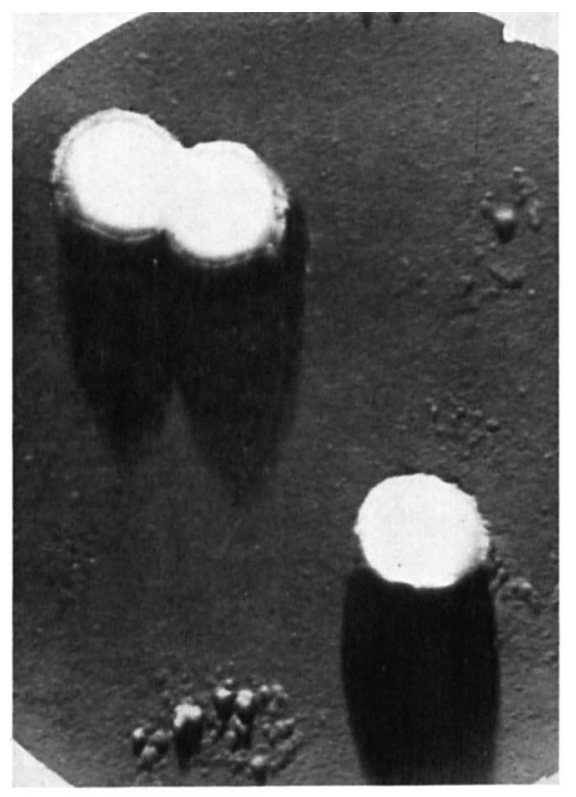

Fig. 1

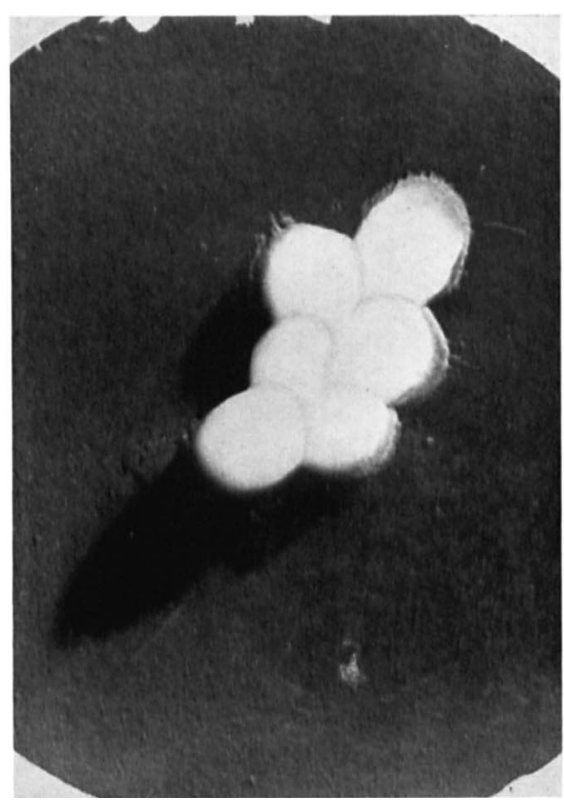

Fig. 3

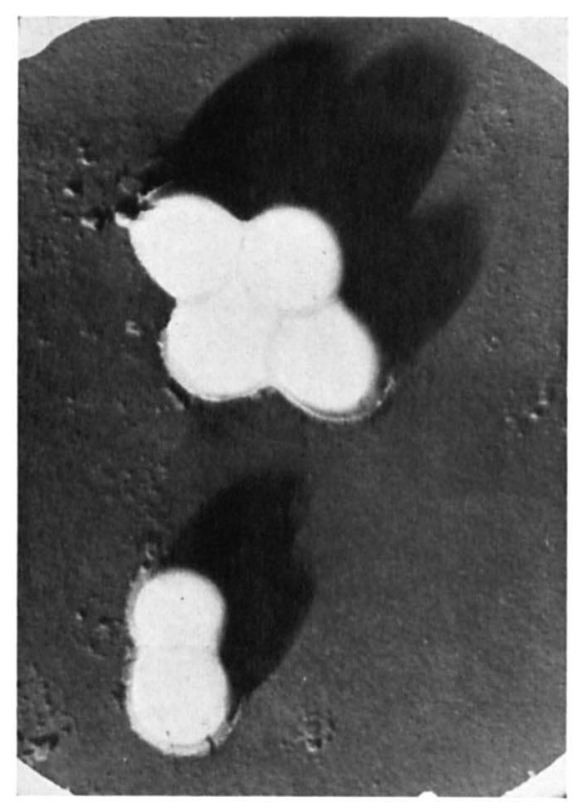

Fig. 2

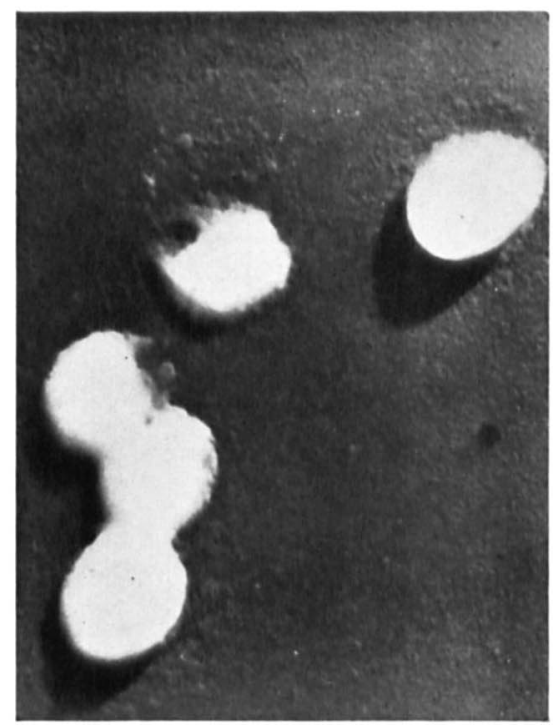

Fig. 4

M. R. J. Salton, R. W. Horne \& V. E. Cosslett-Electron microscopy of CTABtreated bacteria. Plate 1 
Journal of General Microbiology, Vol. 5, No. 2

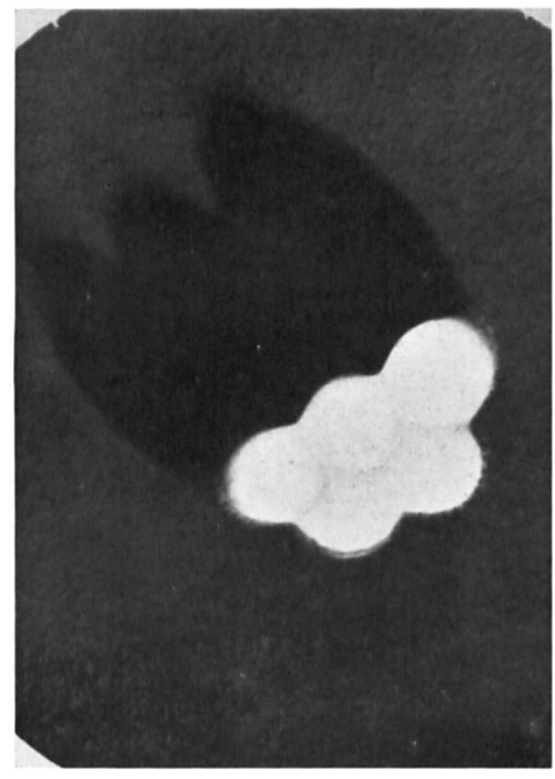

Fig. 5

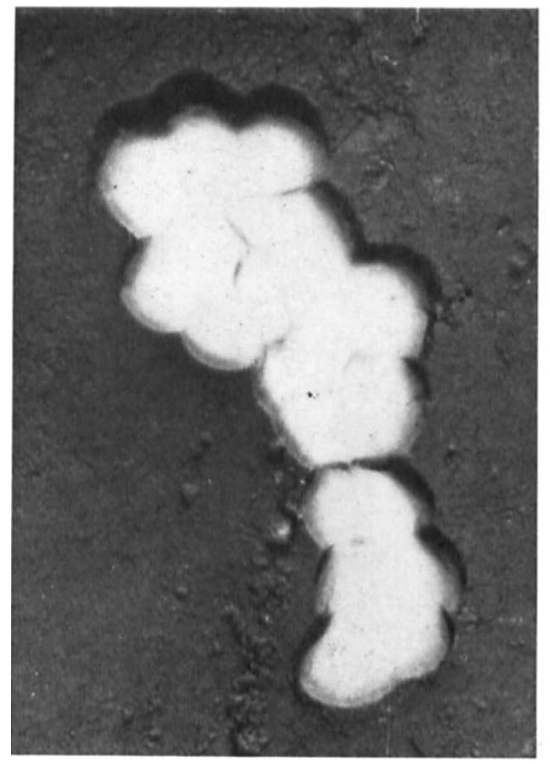

Fig. 7

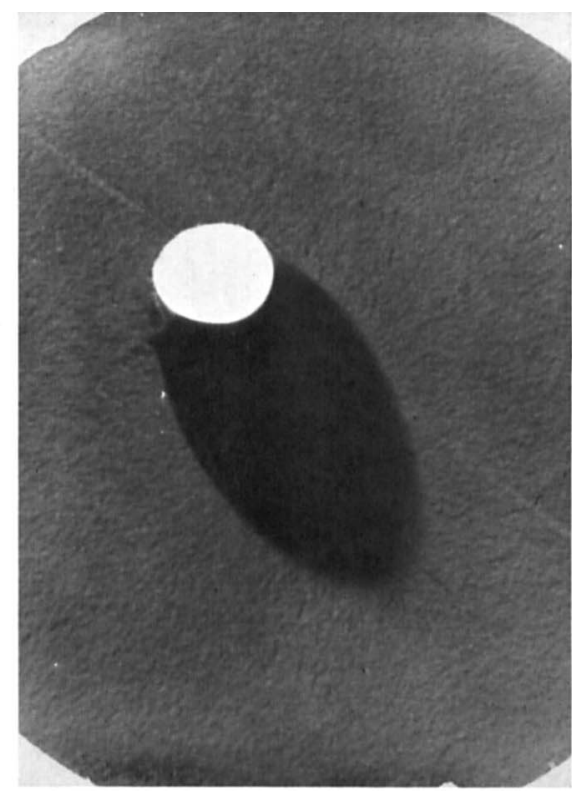

Fig. 6

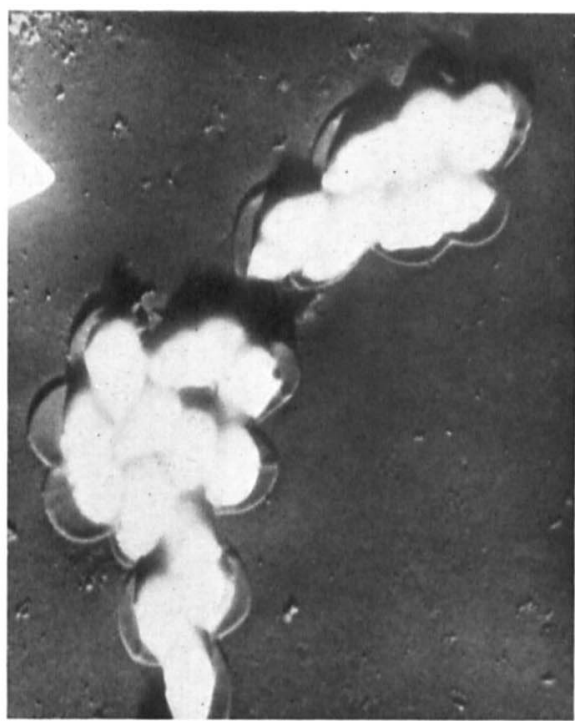

Fig. 8

M. R. J. Salton, R. W. Horne \& V. E. Cosslett-Electron microscopy of CTABtreated bacteria. Plate 2 
Journal of General Microbiology, Vol. 5, No. 2

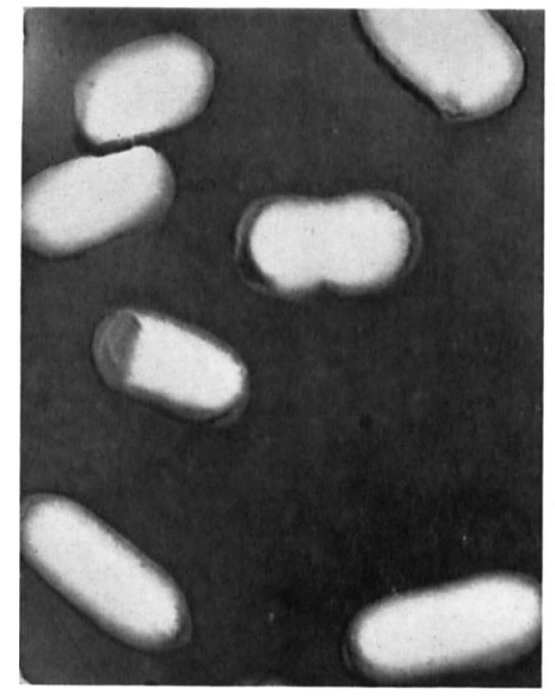

Fig. 9

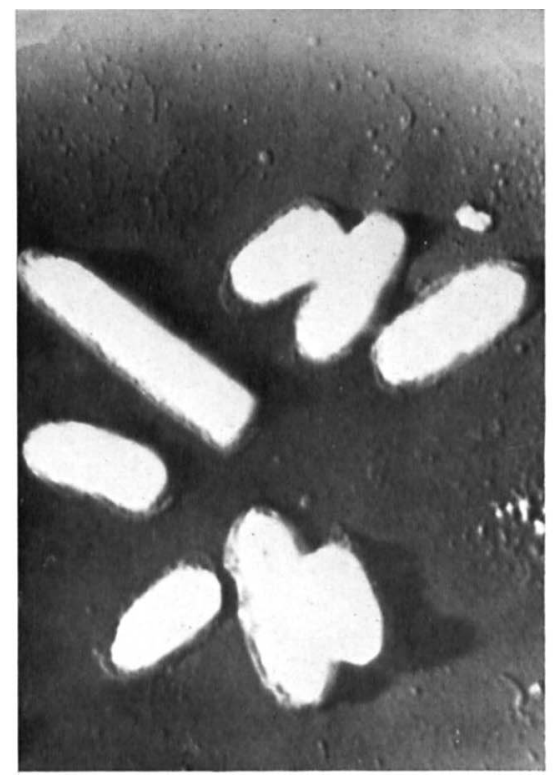

Fig. 11

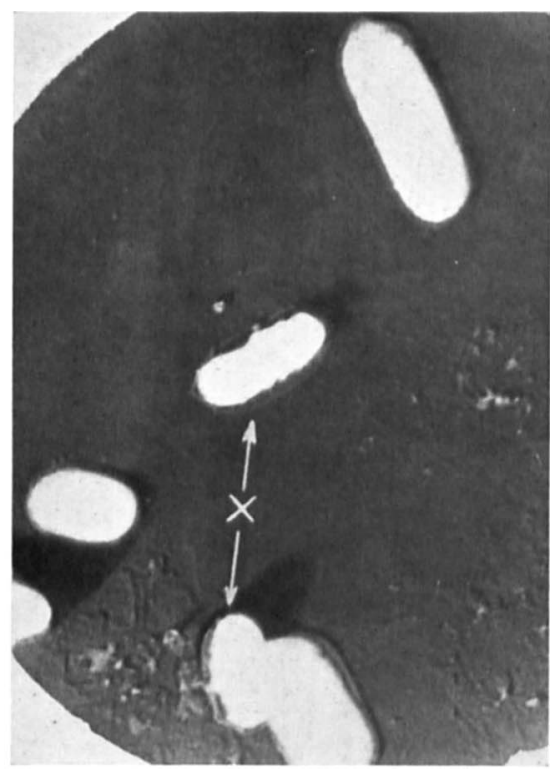

Fig. 10

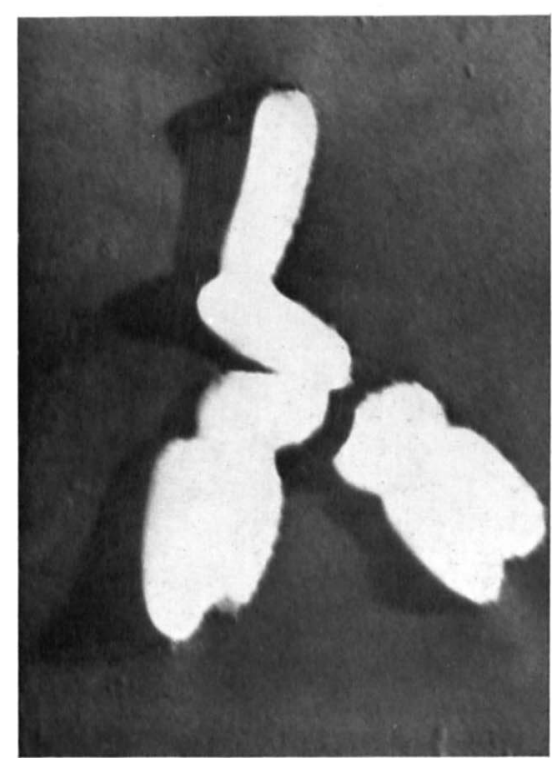

Fig. 12

M. R. J. Salton, R. W. Horne \& V. E. Cosslett-Electron microscopy of CTABtreated bacteria. Plate 3 
from the cell wall which can be seen clearly as an outer envelope enclosing the cytoplasm. However, when CTAB-treated cells are allowed to autolyse or when cells are treated with larger amounts of CTAB, the cell wall itself is either partly or completely stripped off. Permeability alterations by CTAB can thus be observed at lower CTAB concentrations than those required to strip off the outer cell envelopes.

\section{REFERENCES}

Dyar, M. T. (1947). A cell wall stain employing a cationic surface active agent as a mordant. J. Bact. 53, 498.

Gale, E. F. \& TAYLOR, E. S. (1947). The assimilation of amino-acids by bacteria. 2. The action of tyrocidin and some detergent substances in releasing aminoacids from the internal environment of Streptococcus faecalis. J. gen. Microbiol. $1,77$.

Meisel, M. N. \& Umanskaya, V. P. (1949). On the action of quaternary ammonium compounds on the bacterial cell. Mikrobiol. (U.S.S.R.) 18, 11.

Mitchell, P. D. \& Crowe, G. R. (1947). A note on electron micrographs of normal and tyrocidin-lysed Streptococci. J. gen. Microbiol. 1, 85 .

Salton, M. R. J. (1951). The adsorption of cetyltrimethylammonium bromide by bacteria, its action in releasing cellular constituents and its bactericidal effects. J. gen. Microbiol. 5, 391.

WyскоFғ, R. W. G. (1949). Electron Microscopy Techniques and Applications, Chap. v. New York: Interscience Publishers Inc.

\section{EXPLANATION OF PLATES}

All photographs are electron micrographs of preparations shadowed with Au (60\%)Pd (40\%) alloy.

Plate 1

Fig. 1. Staph. aureus. Distilled water suspension. $\times 18,000$.

Fig. 2. Staph. aureus treated with $90 \mu \mathrm{g}$. CTAB $/ \mathrm{ml}$. for $30 \mathrm{~min}$. at $20^{\circ} . \times 18,000$.

Fig. 3. Staph. aureus treated with $90 \mu \mathrm{g}$. CTAB $/ \mathrm{ml}$. for $30 \mathrm{~min}$. at $20^{\circ} . \times 18,000$.

Fig. 4. Staph. aureus treated with $90 \mu \mathrm{g}$. CTAB $/ \mathrm{ml}$. for $28 \mathrm{hr}$. at $30^{\circ} . \times 22,000$.

\section{Plate 2}

Fig. 5. Staph. aureus treated with $900 \mu \mathrm{g}$. CTAB $/ \mathrm{ml}$. for $30 \mathrm{~min}$. at $20^{\circ} . \times 18,000$.

Fig. 6. Staph. aureus treated with $900 \mu \mathrm{g}$. CTAB $/ \mathrm{ml}$. for $30 \mathrm{~min}$. at $20^{\circ} . \times 18,000$.

Fig. 7. Strep. faecalis. Distilled water suspension. $\times 10,500$.

Fig. 8. Strep. faecalis treated with $90 \mu \mathrm{g}$. CTAB $/ \mathrm{ml}$. for $30 \mathrm{~min}$. at $20^{\circ} . \times 11,000$.

Plate 3

Fig. 9. Esch. coli. Distilled water suspension. $\times 8,500$.

Fig. 10. Esch. coli (1.5 mg. dry weight) treated with $45 \mu$ g. CTAB for 5 min. at $20^{\circ}$. ' $X$ ', indicates cells in which the cytoplasm has contracted from the cell envelope; note that the contracted cytoplasm casts appreciably more shadow. $\times 8,500$.

Fig. 11. Esch. coli treated with $90 \mu \mathrm{g}$. CTAB $/ \mathrm{ml}$. for $30 \mathrm{~min}$. at $20^{\circ} . \times 9,000$.

Fig. 12. Esch. coli treated with $900 \mu \mathrm{g}$. CTAB $/ \mathrm{ml}$. for $30 \mathrm{~min}$. at $20^{\circ} . \times 8,500$. 